\title{
Formation of a Regional Process Management Model for Energy Efficiency of Low-Rise Residential Construction
}

\author{
Ekaterina A. Zharova \\ Nikolay N. Minaev \\ Kristina E. Filushina \\ Aleksandr M. Gusakov \\ Natalia V. Gusakova \\ Tomsk State University of Architecture and Building, Russian Federation \\ Email: lightmoon@sibmail.com
}

\section{Doi:10.5901/mjss.2015.v6n3s5p155}

\section{Abstract}

Article is devoted to the formation of a regional model of development and management of processes to improve energy efficiency of low-rise residential construction in Russia. Authors define the role and place of low-rise construction in the national socio-economic priorities, as well as the method of forming regional models. Developed a set of indicators to measure the effectiveness of the implementation of the model. The analysis and evaluation revealed the ineffectiveness of the existing state of regional development programs for low-rise construction. The main objective of the study is to develop a theoretical basis and practical recommendations for the formation of affordable low-rise housing that meets the requirements of energy efficiency and environmental friendliness. Authors have solved the problem of forming a model based on a systematic and interdisciplinary approaches, and demonstrate the effects associated with its implementation. The study uses the methods and principles of object-logical, structural-functional and systemic analysis, systemic and target-oriented approaches, tools, indicative planning and situational modeling. The study developed a model of development and implementation of regional development programs for low-rise housing to meet the requirements of energy efficiency. Study results presented in the article can be used by the authorities in the development of territorial planning documents (i.e. regional and national programs for the development of low-rise housing construction).

Keywords: energy efficiency, energy saving, low-rise residential construction, regional governance, regional economy, regional sectoral programs

\section{Introduction}

The development of low-rise residential construction (hereinafter - LRC) is certainly one of the key socio-economic development priorities of countries with, on the one hand, largely unsolved problem of providing a comfortable and affordable housing, on the other hand, with substantial undeveloped and untapped territories (see Aalto et al., 2012; Andelin et al., 2015; Eerikäinen \& Sarasoja, 2013; Heinonen \& Junnila, 2014). Among these countries, first of all, is the Russian Federation. The practice of implementation of institutional reforms at the national level and the implementation of major infrastructure projects in the construction showed the state's inability to effectively solve the housing problem by applying conventional mechanisms and tools (see Filushina \& Merkuleva, 2014; Filushina et al., 2014b; Minaev et al., 2014a). Moreover, the most important strategic documents do not reflect the need for intensive development of low-rise building, while construction industry has proved to be quite vulnerable, both in terms of internal factors (low efficiency) as well as from the perspective of global changes in the world economy, depriving the construction companies from access to cheap credit.

Identified problems define the purpose and objectives of the study, which include study of the role and place of the low-rise residential construction in the national socio-economic priorities of Russia. Figure 1 shows the global challenges and trends in socio-economic development of Russia. They all boil down to the need for a consistent and systematic approach to solving problems of regional development, with a key role being assigned to the mechanisms of low-rise residential construction used. 


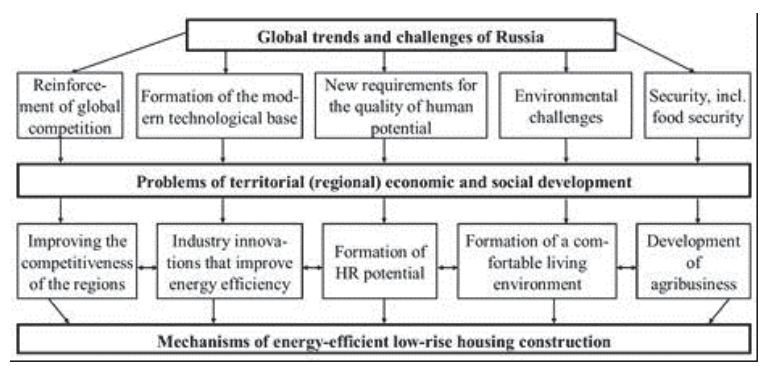

Figure 1. Justification of the role and place of the LRC in the national socio-economic priorities

\section{Low-rise Residential Construction in the Russian Federation}

So far, the scope of residential construction in Russia is developing in accordance with the objectives laid down in the federal program "Housing" for 2011 - 2015 years, which are reduced to the formation of an affordable housing market of economy-class that meets the requirements of energy efficiency and environmental friendliness, as well as enable to perform state obligations to provide housing for groups of citizens, established by federal law. At the same time, it is worth noting that over the past 5 years there has been a trend of excess growth of low-rise residential construction growth of multi-storey apartment buildings, which indicates the high demand for low-rise housing (Minaev et al., 2014b).

At the same time, the rapid development of low-rise construction hampered by a number of existing problems, among which are the lack of adequate regional legal framework, lack of areas with engineering set up, inaccessibility of the objects of low-rise construction for some groups of citizens, which is caused by the use of traditional costly construction technologies, as well as the problem of the lack of technical regulations and development of national standards in terms of energy efficiency of low-rise construction.

Solutions to the problems should be based on models of interaction of the governance subjects, motivated (by law) to actively implement energy-saving technologies and energy efficiency of low-rise construction to meet the requirements of technical regulations, which will ultimately provide the necessary socio-economic effects that compensate for the barriers of development (Minaev et al., 2014; Junnila \& Ristimäki, 2011). Implementation models should also contribute to the problem of resettlement of old and dilapidated housing stock.

The model involves the development of a set of measures aimed at the development of low-rise residential construction in accordance with the prevailing trend of socio-economic development of the region (Filushina et al., 2014a). It identifies the main actors of the program and their functions, the strategic priorities of low-rise construction, the criteria for determining the optimal inventory of modern energy efficient technologies, etc.

\section{Management Model for Energy Efficiency of Low-Rise Residential Construction}

The proposed model is based on an interdisciplinary, system and program-oriented approaches, methods of indicative planning, providing benefits to the suggested model in comparison to models being implemented in the framework of federal and regional programs (Figure 2).

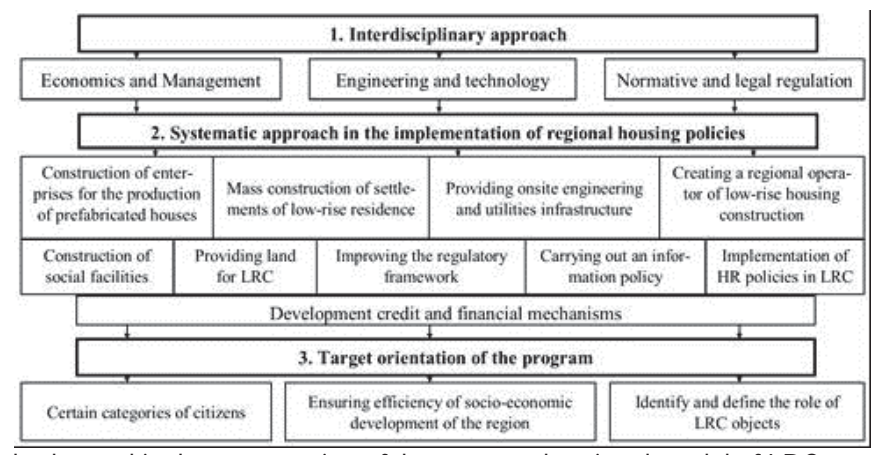

Figure 2. Research methods used in the construction of the proposed regional model of LRC 
Systematic approach should include the elements present in scheme 2 that take into account the diversity of relationships during the investment projects of low-rise residential construction. It is important to have a developed system of indicators of socio-economic development in the context of the implementation of programs and activities of the LRC at the stage of the model development (Figure 3). It contains two groups of indicators: measurable and unmeasurable, both of which clearly demonstrate the success of the program, projected on a number of important LRC processes in the region.

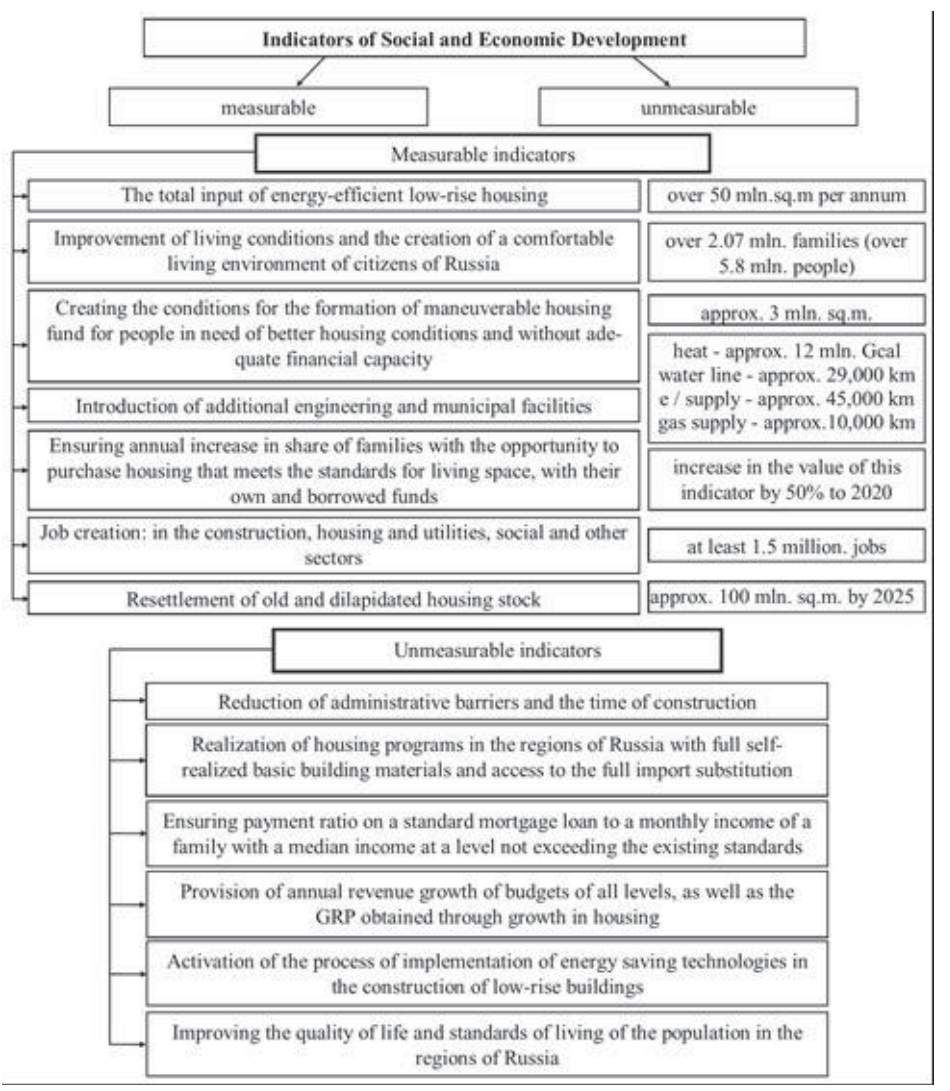

Figure 3. Indicators of the effectiveness of implementation of the regional model of LRC

\section{Reflecting on the Effects from Implementation of the Regional Model of LRC}

The model, on the one hand, has a pronounced social orientation, and on the other hand, contains a commercial and economic effects, which consist of two components. Firstly, the commercial effects that arise during the construction from introducing new technologies and building materials. By introducing innovative technologies, it is possible to achieve a significant reduction in the cost of 1 sq.m. of housing and follow-up costs for its operation. The implementation of such schemes of effects can be performed in the framework of the energy service contracts, similar to those implemented at the facilities of long-term operation. The essence of the scheme is a multilateral agreement between the customerbuilder, contractor, financial and credit institutions and authorities, which provides for the phased co-financing of the facility construction, taking into account the implementation of energy efficient technologies in the field of municipal support, reducing the amount of energy consumption during the construction phase. As a result, there is a commercial effect, which is directed in part to repay the loans, partially reduces the cost per square meter of housing, and partially generates additional revenues by a contractor. Authorities do not participate in the direct distribution of these effects, but for them the effectiveness of the project consists in reducing the volume of financing the share of housing provided to the privileged categories of citizens. Secondly, economic effects that arise during long-term operation of the low-rise residential construction. Mechanism to ensure their acquirement should be the performance contract signed between the 
association of homeowners (i.e. building society) and operating (utility supplier) organization. Overall, this pattern of interaction has been well studied and has a positive practice, mainly in Western Europe.

These effects are formed on the basis of:

Reducing the consumption of utility resources in terms of 1 apartment (house) for the owner. These savings can reach 25 to 75 percent of the total cost of housing and communal services. Mathematically this can be expressed as follows (1):

$\Delta \mathrm{E}$ con $=\sum \mathrm{K}_{\mathrm{t}}-\sum \mathrm{K}_{\mathrm{n}}$

with, $\sum \mathrm{K}_{\mathrm{t}}-$ the amount of utility payments using traditional energy-saving technologies;

$\sum K_{n}$ - the amount of utility bills by using new and innovative energy-saving technologies.

- increase of the turnaround time of the low-rise residence. This is an extremely important aspect, since the lowrise residential buildings have a significant drawback to the multi-storey consisting of low density of owners living in terms of $1 \mathrm{~m} 2$ of land under the building. Hence, higher unit costs of the repair and overhaul for 1 owner. Increase of the turnaround time, obviously, makes low-rise housing more attractive in the context of maintenance costs in the medium and long term and forms a stable market value of the subject of low-rise construction in the range of operation from 30 to 50 years.

Should separately identify the technical and technological aspect of implementation of the model, which defines the technical aspects of low-rise construction (Minaev et al., 2015). It is necessary to adhere to the concept of cogeneration and independent power supply as at the construction phase and the operational phase of low-rise housing. The essence of which is the choice of technology, combining the simultaneous production of heat and electricity, water treatment, water supply and sanitation. The use of automation and remote supervisory control should be an integral part of the introduction of new energy-efficient technologies. Provided that the above processes must be taken into account during the development of design and construction documents.

The following incentives should be considered for implementation of the given model in mass in the Russian regions:

- The introduction of tax benefits (e.g. tax on personal property) imposed on objects of low buildings that meet the requirements of energy efficiency (a confirmed class energy efficiency of not less than $\mathrm{C}$ );

- The introduction of a moratorium on limiting alienation (i.e. sale) of land obtained on favorable terms for lowrise construction;

- Setting a deadline of construction and commissioning of low-rise construction;

- Providing preferential (i.e. subsidized) rate loans for low-rise construction contractors for companies and for homeowners;

- The allocation of additional transfers to the regions, ensuring a high rate of energy-efficient low-rise building (including, for the privileged categories of citizens).

Thus, the proposed model of development and management processes to improve energy efficiency of low-rise residential building in Russia is designed to provide the formation of a comfortable and safe living environment of Russian citizens; sustainable development of regional investment and construction industry; introduction of new energy technologies; the effective demand for low-rise housing; the development of manufacturing industry of new building materials; solution of the complex of social problems (e.g. housing for young families, professionals, academics, public sector employees, etc.); enhancing regional economic processes and increase the gross regional product. In addition, this model leads to an increase in the practical built-up areas, increase the number of people living in individual homes, the need for significant measures for the development of engineering and transport utilities and social infrastructures, as well as the creation of new jobs.

Practical and theoretical significance of the research expressed in two directions: Firstly, the results of the use of theoretical approaches to the study of the economic nature of the low-rise housing, allowed to explore the economic nature of the low-rise residential buildings, its place and role in the system of national priorities; secondly, the methodological tools used and practical recommendations given (e.g. program activities) enable to realize the potential of low-rise residential buildings to improve energy efficiency, as well as economic and commercial efficiency of regional investment and construction projects of low-rise housing construction.

\section{Concluding Remarks}

The formation of a regional model of process control to improve energy efficiency of low-rise housing should be based on the effectiveness of the implementation of regional development programs for low-rise housing construction in the context 
of the given indicators. The interrelation and intersection the policy documents with the requirements of energy efficiency is extremely important, as it will provide its complexity at the development phase, and the phases of the direct implementation of specific projects (e.g. engineering, technology). The regulatory framework in the field of low-rise housing has to be significantly improved, precisely, it relates to documents of technical regulation. It is clear that regional programs should be formed in a single methodological and methodical basis. In turn, this will ensure a balance of regional policy on the scale of Russia.

\section{Acknowledgment}

This article is prepared with the financial support of the Russian Foundation for Humanities

\section{References}

Aalto, P., Dusseault, D., Kivinen, M., \& Kennedy, M., (2012). How Are Russian Energy Policies Formulated? Linking Actors and Structures of Energy Policy. In P. Aalto (ed.) Russia's Energy Policies: National, Interregional and Global Levels (pp. 20-44). Cheltenham: Edward Elgar.

Andelin, M., Sarasoja, A., Ventovuori, T., \& Junnila, S. (2015). Breaking the circle of blame for sustainable buildings - evidence from Nordic countries. Journal of Corporate Real Estate, 17 (1), 26-45.

Eerikäinen, H., \& Sarasoja, A., (2013). Marketing green buildings - Well structured process or forgotten minor detail? Evidence from Finland. Property Management, 31 (3), 233-245.

Filushina, K.E., \& Merkuleva, J.A, (2014). Energy efficiency. Proceedings of the International Scientific and Practical Conference "Prospects for the development of science and education".

Filushina, K.E., Merkuleva, J.A, \& Zharova, E.A. (2014a). Model of socio-economic development processes of energy saving. Proceedings of the international scientific-practical conference "The globalization of science: problems and prospects".

Filushina, K.E., Minaev, N.N., \& Dobrynina, O.I. (2014b). Analysis of the development of processes to improve energy efficiency and energy saving in the housing sector. Economy and Entrepreneurship, 6, 104-110.

Heinonen, J., \& Junnila, S. (2014). Residential energy consumption patterns and the overall housing energy requirements of urban and rural households in Finland. Energy and buildings, 76, 295-303.

Junnila, S., \& Ristimäki, M. (2011). Public demand for eco-efficient concepts in urban development. International Journal of Strategic Property management, 16(1), 21-36.

Minaev, N.N., Filushina, K. E., \& Zharova, E.A. (2015). The concept of increasing energy efficiency of low-rise construction in the context of technical regulation. IOP Conference Series: Materials Science and Engineering.

Minaev, N.N., Filushina, K.E., \& Kolyhaeva, J.A. (2014a). Assessment of trends and patterns of development of energy saving processes in the Russian regions. Regional economy: theory and practice, 20, 51-60.

Minaev, N.N., Filushina, K.E., \& Kolyhaeva, J.A. (2014b). Investigation of regularities of energy saving and energy efficiency in Russia's regions. Siberian financial School, 2, 55-60.

Minaev, N.N., Filushina, K.E., \& Merkuleva, J.A. (2014). The concept of energy efficiency of low-rise construction, housing and communal infrastructure in the context of technical regulation. Bulletin of Tomsk State University of Architecture and Building, 5, 59-66. 
